\title{
Respons Pertumbuhan Bibit Salak (Salacca edulis L.) terhadap Dosis Spora Endomikoriza pada Media Pembawa Pasir Vulkanik dan Pasir Laut
}

\author{
DEWA AYU ARI FEBRIYANTI, I WAYAN WIRAATMAJA, DAN \\ I KETUT SUADA* \\ Program Studi Agroekoteknologi Fakultas Pertanian Universitas Udayana \\ Jl. P.B. Sudirman Denpasar Bali 80232 \\ ${ }^{*}$ E-mail: ketutsuada@unud.ac.id
}

\begin{abstract}
Response of Salak Seedling (Salacca edulis L.) Growth to Endomycorrhizal Spore Doses on Volcanic Sand and Sea Sand Carrier. Endomycorrhizae has several benefits, such as increase water absorption and nutrients of plant, protect plants from root pathogens and toxic substances, play a role in improving soil structure, and increase nutrient solubility. This study aimed to determine the growth response of salak seedlings to doses of endomycorrhizal spores in media carrying volcanic sand and sea sand. This study used a factorial randomized block design (RBD) with two treatments i.e. the number of spores and the type of carriers media. The results showed no significant interaction between the number of mycorrhizal spores doses with the carrier media on all observed variables. Spores doses significantly affected stem diameter and root mycorrhizal infection variables. The highest stem diameter was achieved at the dose of 75 spores that was $1.60 \mathrm{~cm}$ which was significantly different from control $(1.28 \mathrm{~cm})$, whereas the highest root infection was obtained at the dose of 225 spores $(92.50 \%)$ which significantly higher than control $(36.25 \%)$. At the observation of 4 MAP (month after planting) the highest root infection was obtained at the dose of 150 spores $(82.50 \%)$ compared to control (10.00\%). Volcanic sand carrier media produced the highest plant dry weight $(3.59 \mathrm{~g})$ which was significantly different to the sea sand $(2.43 \mathrm{~g})$.
\end{abstract}

Keywords: Endomycorrhizae, dose of endomycorrhizae spore, carrier media

\section{PENDAHULUAN}

Petani dalam usaha meningkatkan

produktivitas salak jarang menggunakan jenis pupuk anorganik, sebab pupuk anorganik berdampak negatif terhadap kondisi tanah dan lingkungan, yaitu menyebabkan tanah menjadi padat, kandungan unsur hara dalam tanah menurun, 
DEWA AYU ARI FEBRIYANTI. et al. Respons Pertumbuhan Bibit Salak (Salacca edulis...

dan pencemaran lingkungan. Selain itu pemberian pupuk anorganik secara terusmenerus dalam jangka waktu panjang dapat meningkatkan keasaman tanah dan keberadaan mikroorganisme dalam tanah terganggu sehingga akhirnya kesuburan alami tanah akan menurun (Triyono et al., 2013). Hasil wawancara dengan petani salak di Desa Selat-Karangasem, Bali tahun 2018, petani hanya memanfaatkan serasah daun salak untuk pemupukan, sehingga lahannya sering kekurangan unsur hara dan akibatnya produktivitas tanaman salak menurun. Usaha untuk meningkatkan kesuburan tanah dan kelestarian lingkungan agar produktivitas tanaman tetap tinggi, diperlukan teknik budidaya melalui penggunaan pupuk hayati. Salah satu sumber pupuk hayati adalah fungi mikoriza arbuskula (FMA) (Delvian, 2003).

Fungi mikoriza arbuskular merupakan bentuk asosiasi antara fungi dan akar tumbuhan tingkat tinggi. Bentuk asosiasi yang terjadi antara fungi dengan tanaman adalah bentuk asosiasi yang saling menguntungkan (simbiosis mutualisme), yaitu fungi memperoleh nutrisi dari tanaman dan tanaman memperoleh tambahan serapan air dan hara (Warouw dan Kainde, 2010). Pemanfaatan FMA sebagai pupuk hayati dapat digunakan sebagai alternative untuk menghindari kerusakan tanah akibat penggunaan pupuk anorganik (Sundari et al., 2011). FMA berpotensi besar sebagai pupuk hayati karena dapat memfasilitasi penyerapan hara dalam tanah sehingga dapat meningkatkan pertumbuhan tanaman (Prihastuti, 2007).

Mikoriza adalah jamur yang memerlukan media untuk tumbuhnya. Media tumbuh yang tepat dapat memacu perkecambahan spora menjadi miselium yang mampu menginfeksi akar sebelum mengadakan simbiosis dengan tanaman inang. Disamping unsur hara, terutama fosfor (P), kelembaban air yang cukup, $\mathrm{pH}$ media yang tepat sangat diperlukan untuk mendukung perkecambahan dan perkembangan spora. Unsur hara $\mathrm{P}$ media yang tinggi tidak memacu pertumbuhan miselium termasuk simbiosisnya dengan tanaman inang (Sastrahidayat, 2011). Sementra $\mathrm{pH}$ media yang diperlukan oleh Glomus sp. adalah pH 5,5-6,5. Suhu $28-34^{\circ} \mathrm{C}$ akan memacu infeksi miselium pada tanaman sementara suhu $30^{\circ} \mathrm{C}$ adalah suhu optimum pembentukan arbuskular pada sel akar tanaman dan suhu $35^{\circ} \mathrm{C}$ adalah suhu optimum untuk sporulasi dan perkembangan vesikel (Winarsih dan Baon, 2004; Sastrahidayat, 2011). Oleh karena itu, dalam upaya pemanfaatan mikoriza pada tanaman salak, baik sebagai media pembawa dalam 
pupuk kemasan maupun media tumbuh perlu dicari jenis media yang tepat agar mikoriza dapat membantu pertumbuhan tanaman secara optimal.

Penelitian ini dilakukan dengan tujuan untuk mengetahui dosis spora genus endomikoriza yang diperlukan oleh media pembawa pasir vulkanik dan pasir laut supaya pertumbuhan bibit salak menjadi lebih baik. Berapa dosis spora genus endomikoriza yang optimal diperlukan oleh media pembawa, belum diketahui secara pasti. Oleh karena itu, perlu dilakukan penelitian respon pertumbuhan bibit salak (Salacca edulis L.) terhadap dosis spora endomikoriza pada media pembawa pasir vulkanik dan pasir laut.

\section{BAHAN DAN METODE}

Penelitian dilaksanakan dari bulab Agustus 2018 sampai Maret 2019. Tempat pengambilan sampel tanah dilakukan di Desa Selat Kabupaten Karangasem. Isolasi dan identifikasi endomikoriza dilaksanakan di Laboratorium Sumberdaya Genetik dan Biologi Molekuler Universitas Udayana. Perbanyakan spora endomikoriza dilaksanakan di Laboratorium Agronomi dan Hortikultura. Pengamatan terhadap variabel pertumbuhan tanaman dilaksanakan di
Kebun Percobaan Fakultas Pertanian Universitas Udayana.

Alat-alat yang digunakan dalam penelitian ini adalah tissue, kantong plastik, kertas label, pinset, cawan petri, oven, object glass, cover glass, mikroskop stereo, mikroskop compound, timbangan, gelas beaker, sendok, mesin sentrifus, botol semprot, pipet mikro, pipet tetes, timbangan, lemari pendingin, jarum oose, polibeg, serta satu set saringan dengan diameter lubang 1 $\mathrm{mm}, 500 \mu \mathrm{m}, 212 \mu \mathrm{m}, 106 \mu \mathrm{m}$, dan $53 \mu \mathrm{m}$.

Bahan yang digunakan dalam penelitian ini adalah tanah sampel, larutan jhonson, endomikoriza jenis Glomus sp., pupuk urea, pupuk daun digrow, pupuk kandang, pasir vulkanik, dan pasir laut.

$$
\text { Penelitian ini menggunakan }
$$

Rancangan Acak Kelompok (RAK) dengan dua faktor perlakuan, yaitu: jumlah spora (D) dan jenis media pembawa spora (M). Faktor jumlah spora genus endomikoriza terdiri atas 4 taraf, yaitu: $\mathrm{D}_{0}=0$ spora per $500 \mathrm{~g}$ bahan pembawa (kontrol), $\mathrm{D}_{1}=75$ spora per $500 \mathrm{~g}$ bahan pembawa, $\mathrm{D}_{2}=150$ spora per $500 \mathrm{~g}$ bahan pembawa, $\mathrm{D}_{3}=225$ spora per $500 \mathrm{~g}$ bahan pembawa. Faktor jenis media pembawa spora endomikoriza genus Glomus (M) terdiri atas 2 taraf, yaitu: $\mathrm{MV}=$ pasir vulkanik dan $\mathrm{ML}=$ pasir laut. Terdapat 8 perlakuan kombinasi yang diulang sebanyak 
DEWA AYU ARI FEBRIYANTI. et al. Respons Pertumbuhan Bibit Salak (Salacca edulis...

8 kali sehingga terdapat 64 polibeg (unit) percobaan, 32 polibeg dipanen saat berumur 2 bulan dan 32 polibeg dipanen saat umur 4 bulan.

Isolasi spora dilakukan di

Laboratorium Sumber Daya Genetik dan Biologi Molekuler Universitas Udayana. Metode yang digunakan adalah metode tuang-saring dan dilanjutkan dengan teknik sentrifus dengan menimbang tanah sampel sebanyak $50 \mathrm{~g}$, kemudian dilarutkan dalam $1.000 \mathrm{ml}$ air dan $700 \mathrm{~g}$ gula dan diaduk merata. Selanjutnya campuran tersebut disaring dalam satu set saringan dengan diameter lubang $1 \mathrm{~mm}, 500 \mu \mathrm{m}, 212 \mu \mathrm{m}, 106$ $\mu \mathrm{m}$, dan $53 \mu \mathrm{m}$ secara berurutan dari atas ke bawah (dari diameter lubang terbesar ke terkecil). Saringan bagian atas disemprot dengan air kran untuk memudahkan bahan saringan lolos. Setelah saringan paling atas dilepas kemudian saringan kedua kembali disemprot dengan air kran. Tanah yang tersisa pada saringan $500 \mu \mathrm{m}, 212 \mu \mathrm{m}, 106$ $\mu \mathrm{m}$ dan $53 \mu \mathrm{m}$ dipindahkan ke tabung sentrifus, lalu ditambahkan air dan gula selanjutnya disentrifus dengan kecepatan $2.000 \mathrm{rpm}$ selama 3 menit. Larutan supernatan hasil sentrifus yang masih mengandung larutan gula kemudian dibilas dengan air dan aquades pada saringan dengan diameter lubang $53 \mu \mathrm{m}$ dan hasil bilasan diletakkan pada cawan petri, selanjutnya diamati dibawah mikroskop stereo untuk mengetahui jumlah spora yang terdapat pada $50 \mathrm{~g}$ tanah sampel.

Biji salak dibersihkan dari sisa-sisa daging buah yang masih melekat lalu direndam dan dicuci, dimasukkan ke dalam kantong plastik yang sudah dilubangi, lalu diletakkan di tempat teduh dan lembab sampai kecambah berumur 20-30 hari. Bibit yang telah siap digunakan penelitian ditanam dalam polibeg dengan ukuran $5 \mathrm{~kg}$ yang diisi dengan tanah campur pupuk kandang sebanyak $3 \mathrm{~kg}$ yang dikukus selama 45 menit dengan perbandingan 3:1 dan pemberian dosis media pembawa pasir vulkanik dan pasir laut sebanyak $500 \mathrm{~g}$ yang diletakkan pada kedalaman $10 \mathrm{~cm}$ dari permukaan tanah dalam polibeg dan menyentuh perakaran bibit tanaman salak.

Pupuk diberikan dengan cara penyemprotan lewat daun tanaman (pupuk daun) dan pemberian hara Jhonson dilakukan pada saat tanaman berumur 1 minggu setelah dipindahkan langsung ke polibeg, pemberian hara Jhonson berfungsi untuk mengikat endomikoriza Glomus pada perakaran bibit salak agar endomikoriza Glomus yang terdapat pada perakaran bibit salak bertahan dengan baik. Setelah tanaman berumur 1 bulan dilakukan pemupukan secara bertahap 
yaitu menggunakan pupuk urea dan pupuk daun digrow.

Variabel yang diamati pada penelitian ini adalah jumlah daun, luas daun, tinggi tanaman, diameter batang tanaman, panjang akar dan berat kering, kandungan klorofil daun, tingkat infeksi mikoriza pada akar, dan jaringan $\mathrm{P}$ tanaman.

Data hasil isolasi dan identifikasi ditabulasi dan dianalisis secara deskriptif, sedangkan data hasil tinggi tanaman, diameter batang, luas daun, jumlah daun, klorofil daun, panjang akar, berat segar tajuk, berat segar akar, berat kering oven tajuk, berat kering oven akar, berat segar total, berat kering oven total, infeksi akar, jaringan $\mathrm{P}$ tanaman, dan jumlah akar dianalisis sesuai rancangan yang digunakan. Apabila sidik ragam menunjukkan pengaruh yang nyata, maka dilanjutkan dengan uji BNT taraf 5\%.

\section{HASIL DAN PEMBAHASAN}

Hasil analisis statistik menunjukkan perlakuan media pembawa pada pengamatan umur 2 bulan setelah tanam (BST) berpengaruh nyata terhadap variabel luas daun, jumlah daun, berat segar tajuk, berat segar akar, dan berat segar total serta berpengaruh tidak nyata terhadap variabel tinggi tanaman, diameter batang, klorofil daun, panjang akar, berat kering oven tajuk, berat kering oven akar, bering kering oven total, dan infeksi akar. Sedangkan pada pengamatan 4 BST, media pembawa berpengaruh nyata terhadap variabel jumlah daun, berat segar tajuk, berat kering oven tajuk, berat segar total, berat kering oven total, dan jumlah akar serta berpengaruh tidak nyata terhadap variabel lainnya.

Hasil analisis statistik menunjukkan pengaruh dosis mikoriza pada umur 2 BST berpengaruh nyata terhadap infeksi akar, sedangkan terhadap variabel lainnya berpengaruh tidak nyata. Pada umur 4 BST perlakuan dosis mikoriza berpengaruh nyata terhadap diameter batang dan infeksi akar, sedangkan terhadap variabel lainnya berpengaruh tidak nyata (Tabel 1).

Hasil penelitian menunjukkan tidak terjadi interaksi antara dosis mikoriza dan media pembawa. Hal ini menunjukkan bahwa antara mikoriza dan media pembawa tidak bersinergi secara baik sehingga pertumbuhan bibit tanaman salak tidak optimal. 
DEWA AYU ARI FEBRIYANTI. et al. Respons Pertumbuhan Bibit Salak (Salacca edulis...

Tabel 1. Signifikansi Pengaruh Media Pembawa dan Dosis Mikoriza terhadap Variabel Pertumbuhan Tanaman Salak

\begin{tabular}{|c|c|c|c|c|c|c|c|}
\hline \multirow{3}{*}{ No } & \multirow{3}{*}{ Variabel } & \multicolumn{6}{|c|}{ Perlakuan } \\
\hline & & \multicolumn{2}{|c|}{ Media Pembawa } & \multicolumn{2}{|c|}{ Dosis Mikoriza } & \multicolumn{2}{|c|}{ Interaksi } \\
\hline & & $2 \mathrm{BST}$ & $4 \mathrm{BST}$ & $2 \mathrm{BST}$ & $4 \mathrm{BST}$ & $2 \mathrm{BST}$ & $4 \mathrm{BST}$ \\
\hline 1 & Tinggi Tanaman $(\mathrm{cm})$ & ns & $\mathrm{ns}$ & ns & ns & ns & ns \\
\hline 2 & Lingkar Batang (cm) & $\mathrm{ns}$ & ns & ns & ** & $\mathrm{ns}$ & ns \\
\hline 3 & Luas Daun $\left(\mathrm{cm}^{2}\right)$ & $* *$ & ns & ns & ns & ns & ns \\
\hline 4 & Jumlah Daun (helai) & $* *$ & $* *$ & ns & ns & ns & ns \\
\hline 5 & Klorofil Daun (spad unit) & ns & ns & ns & ns & ns & ns \\
\hline 6 & Panjang Akar $(\mathrm{cm})$ & ns & ns & ns & ns & ns & ns \\
\hline 7 & Berat Segar Tajuk (g) & $* *$ & $* *$ & ns & ns & ns & ns \\
\hline 8 & Berat Segar Akar (g) & $* *$ & ns & ns & ns & ns & ns \\
\hline 9 & Berat Kering Tajuk (g) & ns & $* *$ & ns & ns & ns & ns \\
\hline 10 & Berat Kering Akar (g) & ns & ns & ns & ns & ns & ns \\
\hline 11 & Berat Segar Total (g) & $* *$ & $* *$ & ns & ns & ns & ns \\
\hline 12 & Berat Kering Total (g) & ns & $* *$ & ns & ns & ns & ns \\
\hline 13 & Infeksi Akar (\%) & ns & ns & $* *$ & $* *$ & ns & ns \\
\hline 14 & Jumlah Akar & - & $* *$ & - & ns & ns & ns \\
\hline 15 & Jaringan P Tanaman & - & ns & - & ns & - & ns \\
\hline Ketera & $\begin{aligned} \text { n: }{ }^{*} & \text { : Berpengaruh sangat } \\
& * \quad \text { : Berpengaruh nyata } \\
\text { ns } & \text { : Berpengaruh tidak }\end{aligned}$ & $\begin{array}{l}(\mathrm{P}<0,01 \\
0,05) \\
\mathrm{a}(\mathrm{P} \geq 0,0\end{array}$ & & & & & \\
\hline
\end{tabular}

Penelitian ini menunjukkan bahwa media pembawa pasir vulkanik menyebabkan pertumbuhan bibit salak lebih baik dari pada pasir laut. Berat kering total pada pengamatan 4 BST lebih tinggi $(3,59 \mathrm{~g})$ dibandingkan dengan media pembawa pasir laut (2,43 g) (Tabel 2). Hasil berat kering total yang tinggi didukung dengan tingginya berat segar total $(16,11 \mathrm{~g})$, berat kering tajuk $(6,4 \mathrm{~g})$, berat segar tajuk $(26,22)$, jumlah akar (63,94 helai), dan jumlah daun (3,06 helai), sementara pada pasir laut berat segar total $10,75 \mathrm{~g}$, berat kering tajuk $4,13 \mathrm{~g}$, berat segar tajuk 17,29 g, jumlah akar 22,69 helai, dan jumlah daun 2,56 helai. Pengamatan 2 BST, berat kering total memberikan pengaruh yang tidak nyata, tetapi berat kering total menunjukkan nilai yang cenderung lebih tinggi $(2,46 \mathrm{~g})$. Tingginya nilai berat kering total didukung oleh tingginya berat segar total $(16,11 \mathrm{~g})$, berat kering tajuk $(6,4 \mathrm{~g})$, berat segar tajuk $(26,22)$, jumlah akar $(63,94$ helai), dan jumlah daun (3,06 helai), sementara pada pasir laut berat segar total $10,75 \mathrm{~g}$, berat kering tajuk $4,13 \mathrm{~g}$, berat segar tajuk 17,29 g, jumlah akar 22,69 helai, dan jumlah daun 2,56 helai. Pasir vulkanik merupakan bahan yang kaya akan unsur hara sehingga berpotensi meningkatkan kesuburan tanah pertanian di kemudian hari dan dapat 
memperbaharui sumber daya tanah (Munir, 1996).

Komponen material yang dikandung oleh pasir vulkanik diantaranya kuarsa $\left(\mathrm{SiO}_{2}\right)$, aluminium oksida $\left(\mathrm{Al}_{2} \mathrm{O}_{3}\right)$, besi oksida $\left(\mathrm{Fe}_{2} \mathrm{O}_{3}\right)$ dalam jumlah sangat tinggi, selain itu juga terkandung unsur $\mathrm{Ca}, \mathrm{Mg}, \mathrm{Na}$ serta material lainnya (Hartosuwarno, 2010). Mineral pasir vulkanik memiliki fraksi yang didominasi oleh sebagaian besar pasir dengan kejenuhan basa dan kandungan silika yang tinggi. Fungsi pasir vulkanik selain mampu memperbaiki struktur, mengurangi efek racun asam-asam organik dan lain sebagainya, sedangkan pasir laut cenderung bersifat basa karena kandungan garamnya yang tinggi dan sedikitnya partikel liat. Hasil penelitian Zuraida (1999) menunjukkan bahwa pemanfaatan pasir vulkanik Kelud hasil letusan pada tahun 1990 dapat meningkatkan tinggi tanaman dan bobot kering tanaman. Pasir vulkanik dengan tekstur kasar dan unsur hara yang rendah, sangat baik sebagai medium tumbuh untuk produksi inokulum mikoriza arbuskula. Sedangkan pasir laut mengandung kadar air yang rendah dan kadar garam yang tinggi dapat mengakibatkan tumbuhan mengalami kekeringan. Kekeringan terjadi karena potensi osmotik tanah lebih tinggi daripada potensi osmotik jaringan sehingga menghambat penyerapan air dan unsur hara. Selain itu, kadar bahan organik dalam tanah pasir yang sedikit dapat mengganggu aktivitas fisiologi tumbuhan yang berupa laju transpirasi, laju respirasi, laju fotosintesis dan sintesis protein, sehingga hasil pertumbuhan tanamannya kurang baik.

Penelitian ini menunjukkan dosis mikoriza berpengaruh nyata terhadap diameter batang dan infeksi akar. Hampir semua variabel pengamatan menunjukkan hasil yang tidak nyata. Infeksi akar tertinggi terdapat pada dosis D3 (225 spora) pada pengamatan 2 BST $(92,50 \%)$, tidak berbeda nyata dengan D1 (86,25\%), dan D2 (91,25\%) namun berbeda nyata dengan D0 $(36,25 \%)$. Sedangkan pada infeksi akar 2 BST, infeksi akar tertinggi didapat pada D2 (150 spora) yaitu sebesar $82,50 \%$, tidak berbeda nyata dengan D1 (78,75\%) dan D3 (80,00\%), namun berbeda nyata dengan D0 $(10,00 \%)$. Terjadinya infeksi akar pada perlakuan D0 (kontrol) kemungkinan disebabkan oleh kurang efektifnya sterilisasi pada tanah dan juga terjadinya percikan air pada polibeg tanaman salak sehingga spora mikoriza tersebut dapat berpindah ke polibeg lain dan mengalami simbiosis pada perlakuan tanaman kontrol D0 (kontrol). Diameter batang tertinggi didapat pada pengamatan 4 BST pada D1 (75 spora) yaitu 1,60 cm yang 
DEWA AYU ARI FEBRIYANTI. et al. Respons Pertumbuhan Bibit Salak (Salacca edulis...

tidak berbeda nyata dengan D2 $(1,57 \mathrm{~cm})$ namun berbeda nyata dengan D0 $(1,28 \mathrm{~cm})$ dan D3 (1,44 cm) (Tabel 2). Yudhistira (2012) melaporkan pemberian mikoriza pada bibit jabon hasil biakan generatif mengalami peningkatan diameter batang sebesar 113,95\%. Diduga inokulasi endomikoriza memberikan pengaruh dan respons yang lebih baik terhadap pertumbuhan diameter batang tanaman salak. Menurut hasil penelitian Yudisthira (2012) pertambahan diameter merupakan pertumbuhan sekunder yang mempertebal batang dan akar di daerah tumbuhan yang lebih muda pada diameter batang. Hal ini dapat dilihat dari berat kering total yang cenderung lebih tinggi pada pengamatan 4 BST yaitu D2 (3,42 g) yang tidak berbeda nyata dengan perlakuan lainnya.

Hasil pewarnaan (staining) pada akar tanaman salak yang diamati di bawah mikroskop dengan perbesaran 100 kali ditemukan struktur FMA berupa vesikula, hifa dan arbuskula (Gambar 1). Struktur vesikula yang ditemukan berbentuk oval, sementara hifa berupa benang-benang di antara sel-sel akar tanaman dan arbuskula menggumpal dalam sel. Struktur endomikoriza berwarna biru disebabkan oleh terserapnya trypan blue ke dalam struktur tersebut. Struktur vesikula, arbuskula, dan hifa internal setelah staining pada akar tanaman salak menunjukkan bahwa tanaman mampu bersimbiosis dengan endomikoriza sehingga terjadi infeksi endomikoriza pada akar tanaman salak. Ditemukannya struktur vesikula dan hifa menunjukkan bahwa telah terjadi simbiosis antara tanaman dengan endomikoriza (Suamba et al., 2014). Tinggi rendahnya persentase infeksi endomikoriza pada akar tanaman tergantung pada jenis endomikoriza dan kepekaan akar tanaman inangnya. Selain itu perbedaan persentase tingkat infeksi akar juga dipengaruhi oleh kondisi fisik, bilogi, dan kimia tanah, ketinggian tempat, suhu, jumlah spora, dan tingkat kepekaan tanaman inang (Fakuara, 1988; Sastrahidayat, 2011).

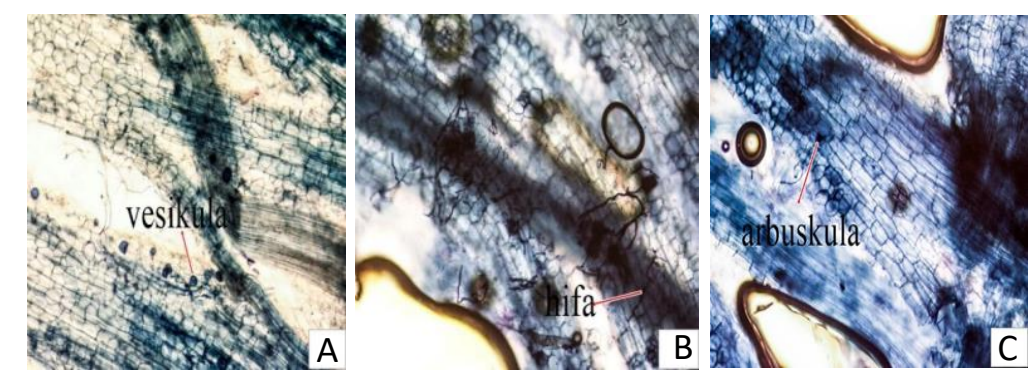

Gambar 1. Struktur Infeksi Endomikoriza. Vesikula (A), Hifa (B), dan Arbuskula (C) pada Akar Tanaman Salak dengan Pembesaran 100 X. 
Tabel 2. Variabel Pertumbuhan Tanaman Salak pada Media Pembawa dan Dosis Endomikoriza

\begin{tabular}{|c|c|c|c|c|c|c|c|c|c|c|}
\hline \multirow{2}{*}{ Perlakuan } & \multicolumn{2}{|c|}{$\begin{array}{l}\text { Luas daun } \\
\left(\mathrm{cm}^{2}\right)\end{array}$} & \multicolumn{2}{|c|}{$\begin{array}{c}\text { Diameter } \\
\text { batang }(\mathrm{cm})\end{array}$} & \multicolumn{2}{|c|}{$\begin{array}{l}\text { Jumlah daun } \\
\text { (helai) }\end{array}$} & \multicolumn{2}{|c|}{$\begin{array}{c}\text { Berat segar } \\
\text { tajuk }(\mathrm{g})\end{array}$} & \multicolumn{2}{|c|}{$\begin{array}{c}\text { Infeksi akar } \\
(\%)\end{array}$} \\
\hline & $\begin{array}{c}2 \\
\text { BST }\end{array}$ & $\begin{array}{c}4 \\
\text { BST }\end{array}$ & $\begin{array}{c}2 \\
\mathrm{BST}\end{array}$ & $\begin{array}{c}4 \\
\text { BST }\end{array}$ & $\begin{array}{c}2 \\
\text { BST }\end{array}$ & $\begin{array}{c}4 \\
\text { BST }\end{array}$ & $2 \mathrm{BST}$ & $\begin{array}{c}4 \\
\text { BST }\end{array}$ & $\begin{array}{c}2 \\
\text { BST }\end{array}$ & $\begin{array}{c}4 \\
\text { BST }\end{array}$ \\
\hline \multicolumn{11}{|c|}{ Media pembawa } \\
\hline -Pasir & 27,33 & 85,40 & 1,27 & 1,54 & 3,06 a & 3,06 & 13,60 & 26,22 & 80,00 & 65.63 \\
\hline Vulkanik & $\mathrm{a}$ & $\mathrm{a}$ & $\mathrm{a}$ & $\mathrm{a}$ & & $\mathrm{a}$ & $\mathrm{a}$ & $\mathrm{a}$ & $\mathrm{a}$ & $\mathrm{a}$ \\
\hline \multirow[t]{2}{*}{-Pasir Laut } & 25,05 & 72,44 & 1,13 & 1,40 & \multirow[t]{2}{*}{$2,63 \mathrm{~b}$} & 2,56 & \multirow[t]{2}{*}{$9,66 \mathrm{~b}$} & 17,29 & 73,13 & 60.00 \\
\hline & $\mathrm{b}$ & $\mathrm{a}$ & $\mathrm{a}$ & $\mathrm{b}$ & & $\mathrm{b}$ & & $\mathrm{a}$ & $\mathrm{a}$ & $\mathrm{a}$ \\
\hline BNT 5\% & 1,27 & 15,21 & 0,14 & 0,14 & 0,32 & 0,34 & 1,70 & 10,45 & 11,7 & 10.17 \\
\hline \multicolumn{11}{|c|}{ Dosis mikoriza } \\
\hline \multirow[t]{2}{*}{ D0 (0\%) } & 26,09 & 66,61 & 1,17 & 1,28 & \multirow[t]{2}{*}{$2,88 \mathrm{a}$} & 2,75 & 11,18 & 16,69 & 36,25 & 10.00 \\
\hline & $\mathrm{a}$ & $\mathrm{a}$ & $\mathrm{a}$ & $\mathrm{b}$ & & $\mathrm{a}$ & $\mathrm{a}$ & $\mathrm{a}$ & $\mathrm{b}$ & $\mathrm{b}$ \\
\hline \multirow[t]{2}{*}{ D1 $(75 \%)$} & 25,49 & 86,68 & 1,12 & 1,60 & \multirow[t]{2}{*}{$2,75 \mathrm{a}$} & 2,75 & 12,16 & 19,40 & 86,25 & 78.75 \\
\hline & $\mathrm{a}$ & $\mathrm{a}$ & $\mathrm{a}$ & $\mathrm{a}$ & & $\mathrm{a}$ & $\mathrm{a}$ & $\mathrm{a}$ & $\mathrm{a}$ & $\mathrm{a}$ \\
\hline \multirow[t]{2}{*}{ D2 (150\%) } & 26,70 & 81,49 & 1,30 & 1,57 & $2,75 \mathrm{a}$ & 2,75 & 11,22 & 26,16 & 91,25 & 82.50 \\
\hline & a & $\mathrm{a}$ & $\mathrm{a}$ & $\mathrm{a}$ & \multirow{3}{*}{$3,00 \mathrm{a}$} & $\mathrm{a}$ & $\mathrm{a}$ & $\mathrm{a}$ & $\mathrm{a}$ & $\mathrm{a}$ \\
\hline \multirow[t]{2}{*}{ D3 $(225 \%)$} & 26,49 & 80,90 & 1,21 & 1,44 & & 3,00 & 11,96 & 24,77 & 92,50 & 80.00 \\
\hline & a & a & $\mathrm{a}$ & $\mathrm{ab}$ & & a & a & $\mathrm{a}$ & a & $\mathrm{a}$ \\
\hline BNT 5\% & 1,79 & 21,51 & 0,20 & 0,20 & 0,47 & 0,47 & 2,4 & 10,45 & 16,54 & 14.38 \\
\hline \multirow[t]{2}{*}{ Perlakuan } & \multicolumn{2}{|c|}{$\begin{array}{c}\text { Berat segar } \\
\text { akar }(\mathrm{g})\end{array}$} & \multicolumn{2}{|c|}{$\begin{array}{c}\text { Berat segar total } \\
(\mathrm{g})\end{array}$} & \multicolumn{3}{|c|}{$\begin{array}{l}\text { Berat kering } \\
\text { tajuk (g) }\end{array}$} & $\begin{array}{l}\text { Berat } \\
\text { kering } \\
\text { total }(\mathrm{g})\end{array}$ & \multicolumn{2}{|c|}{ Jumlah akar } \\
\hline & $\begin{array}{c}2 \\
\mathrm{BST}\end{array}$ & $\begin{array}{c}4 \\
\text { BST }\end{array}$ & $\begin{array}{c}2 \\
\mathrm{BST}\end{array}$ & $4 \mathrm{BST}$ & & 2 & $\begin{array}{c}4 \\
\text { BST }\end{array}$ & $\begin{array}{c}2 \\
\mathrm{BST}\end{array}$ & $\begin{array}{c}4 \\
\mathrm{BST}\end{array}$ & $4 \mathrm{BST}$ \\
\hline \multicolumn{11}{|c|}{ Media pembawa } \\
\hline -Pasir & 4,71 & 6,00 & 8,88 & 16,11 & 3,90 & & 6,14 & 2,46 & 3,59 & 63,94 \\
\hline Vulkanik & $\mathrm{a}$ & $\mathrm{a}$ & $\mathrm{a}$ & $\mathrm{a}$ & $\mathrm{a}$ & & $\mathrm{a}$ & $\mathrm{a}$ & $\mathrm{a}$ & $\mathrm{a}$ \\
\hline -Pasir Laut & 3,22 & 4,01 & 6,44 & 10,75 & 3,05 & & 4,13 & 1,95 & 2,43 & 22,69 \\
\hline & $\mathrm{b}$ & $\mathrm{a}$ & $\mathrm{a}$ & $\mathrm{b}$ & $\mathrm{a}$ & & $\mathrm{b}$ & $\mathrm{a}$ & $\mathrm{a}$ & $\mathrm{a}$ \\
\hline BNT 5\% & 1,18 & 2,14 & 1,09 & 4,55 & 0,84 & & 1,48 & 0,48 & 0,88 & 28,78 \\
\hline Dosis mikor & & & & & & & & & & \\
\hline D0 (0\%) & 3,17 & 3,64 & 7,18 & 10,20 & 3,48 & & 4,16 & 2,18 & 2,43 & 20,00 \\
\hline & $\mathrm{a}$ & $\mathrm{a}$ & $\mathrm{b}$ & $\mathrm{a}$ & $\mathrm{a}$ & & $\mathrm{a}$ & $\mathrm{a}$ & $\mathrm{a}$ & $\mathrm{a}$ \\
\hline D1 (75\%) & $5,36 \mathrm{~b}$ & 4,88 & 8,76 & 12,14 & 3,37 & & 5,00 & 1,98 & 2,95 & 46,75 \\
\hline & & $\mathrm{a}$ & $\mathrm{a}$ & $\mathrm{a}$ & $\mathrm{a}$ & & $\mathrm{a}$ & $\mathrm{a}$ & $\mathrm{a}$ & $\mathrm{a}$ \\
\hline D2 (150\%) & 3,65 & 6,20 & 7,10 & 16,18 & 3,20 & & 5,76 & 2,22 & 3,42 & 54,38 \\
\hline & $\mathrm{a}$ & $\mathrm{a}$ & $\mathrm{a}$ & $\mathrm{a}$ & $\mathrm{a}$ & & $\mathrm{a}$ & $\mathrm{a}$ & $\mathrm{a}$ & $\mathrm{a}$ \\
\hline D3 (225\%) & 3,68 & 5,31 & 7,62 & 15,20 & 3,84 & & 5,62 & 2,43 & 3,42 & 53,13 \\
\hline & $\mathrm{a}$ & $\mathrm{a}$ & $a b$ & $\mathrm{a}$ & $\mathrm{a}$ & & $\mathrm{a}$ & $\mathrm{a}$ & $\mathrm{a}$ & $\mathrm{a}$ \\
\hline BNT 5\% & 1,67 & 3,03 & 1,54 & 6,43 & 1,19 & & 2,09 & 0,68 & 1,24 & 27,66 \\
\hline
\end{tabular}


DEWA AYU ARI FEBRIYANTI. et al. Respons Pertumbuhan Bibit Salak (Salacca edulis...

\section{SIMPULAN}

Tidak terjadi interaksi antara dosis pupuk mikoriza dengan media pembawa pada semua variabel yang diamati. Diameter batang salak tertinggi didapat pada dosis 75 spora yaitu sebesar $1,60 \mathrm{~cm}$ pada umur 4 BST yang berbeda nyata dengan kontrol $(1,28 \mathrm{~cm})$. Infeksi akar tertinggi $(82,5 \%)$ didapat pada dosis 150 spora per tanaman dan berbeda nyata dengan kontrol $(10,00 \%)$. Media pembawa endomikoriza pasir vulkanik memberikan pengaruh terhadap berat kering total tanaman tertinggi yaitu sebesar 3,59 g yang berbeda nyata dengan pasir laut $(2,43 \mathrm{~g})$. Untuk penelitian selanjutnya perlu dilakukan mengenai daya simpan media mikroriza untuk mengetahui optimalisasi pemanfaatan mikoriza dalam kemasan pupuk dengan melibatkan dosis spora dan jenis media pembawa.

\section{UCAPAN TERIMAKASIH}

Kami menyampaikan terimakasih kepada Prof. Dr. Ir. I Gede Putu Wirawan, M.Sc. sebagai Ketua Lab Sumber Daya Genetik dan Biologi Molekuler Universitas Udayana atas fasilitas yang diberikan sehingga penelitian ini dapat kami selesaikan dengan baik dan tepat waktu. Kepada Prof. Dr. Ir. I Nyoman Rai, M.S. kami juga sampaikan rasa syukur atas bahan-bahan yang disediakan karena tanpa itu penelitian

ini tidak dapat kami laksanakan semestinya.

\section{DAFTAR PUSTAKA}

Delvian, (2003). Keanekaragaman dan Potensi Pemanfaatn Fungi Mikoriza Arbuskula (FMA) di Hutan Pantai [Disertasi]. Bogor. Program Pascasarjana. Institut Pertanian Bogor.

Fakuara, M.Y. (1988). Mikoriza, Teori dan Kegunaan dalam Praktek. PAU-IPB. Bogor.

Hartosuwarno. (2010). Sifat Fisik dan Komposisi Abu Vulkanik Gunung Merapi. Kampus UPNVY 16(118):5.

Munir, M. 1996. Tanah-Tanah Utama Indonesia. Dunia Pustaka Jaya, Jakarta.

Prihastuti. (2007). Isolasi dan Karakterisasi Mikoriza Vesikular-arbuskular di Lahan Kering Masam, Lampung Tengah. Berkala Penelitian Hayati 12:99-106.

Suamba, I. W., I. G. P. Wirawan, dan W. Adiartayasa. (2014). Isolasi dan Identifikasi Fungi Mikoriza Arbuskular (FMA) secara Mikroskopis pada Rhizosfer Tanaman Jeruk (Citrus sp.) di Desa Kerta, Kecamatan Payangan, Kabupaten Gianyar. EJurnal Agroekoteknologi Tropika 3(4):201-208.

Sastrahidayat, I.R. (2011). Rekayasa Pupuk Hayati Mikoriza Dalam Peningkatan Produksi Pertanian. UB Press. 238 hal.

Triyono, A., Purwanto, Budiyono. (2013). Efisiensi Penggunaan Pupuk N untuk Pengurangan Kehilangan Nitrat pada Lahan Pertanian. Prosiding Seminar Nasional Pengelolaan Sumber Daya Alam dan Lingkungan 526-531.

Warouw, V. dan R. P. Kainde. (2010). Populasi Jamur Mikoriza Vesikular Arbuskular (MVA) pada Zone Perakaran Jati. Eugenia 16(1):38-45. 
Winarsih, S. dan J.B. Baon. (2004). Inokulasi mikoriza pada Kultur InVitro dan Pengaruhnya terhadap Pertumbuhan Kopi Robusta, Kepadatan Spora, dan Serapan Hara Fosfor. Pelita Perkebunan 20(1):13-23.

Yudhistira, A. (2012). Inokulasi Bakteri dan Fungi Mikoriza Arbuskula pada Semai Jabon (Anthocephalus cadamba (Roxb.) Miq.) di Media Tanah Ultisol. [Skripsi]. Bogor (ID): Institut Pertanian Bogor.

Yunisari, E. (2015). Pengaruh Inokulasi Fungi Mikoriza Arbuskula dari Lokasi Berbeda terhadap Pertumbuhan Bibit Jabon (Anthocephalus Cadamba Roxb Miq.) Hasil Kultur Jaringan. Skripsi. Institut Pertanian Bogor.

Zuraida. (1999). Penggunaan Abu Volkanik sebagai Amelioran pada Tanah Gambut dan Pengaruhnya terhadap Sifat Kimia Tanah dan Pertumbuhan Jagung [Thesis]. Institut Pertanian Bogor. 